\title{
Üstün Yetenekli Öğrencilerin Bilimsel Yaratıcılık ve Bilimsel Problem Çözme ile İlgili Öz Değerlendirmeleri*
}

\section{Feride ERCAN YALMAN**, Salih ÇEPNI'***}

Öz: Üstün yetenekli bireyler sıra dışı potansiyellerinden dolayı insanlığın ilerlemesinde anahtar rol oynamaktadır. Söz konusu potansiyellerin başında yaratıcılık ve problem çözme becerileri yer almaktadır. Bu araştırmada üstün yetenekli öğrencilerin bilimsel yaratıcılık ve bilimsel problem çözme konularında öz değerlendirmeleri incelenmektedir. Araştırmada, nitel araştırma metotlarından durum çalışması tercih edilmiştir. Araştırmaya Trabzon Bilim Sanat Merkezi'nde öğrenim gören 6. sınıf düzeyindeki 21 üstün yetenekli öğrenci dâhil edilmiştir. Yarı yapılandırılmış görüşmeler aracılığı ile öğrencilerden veriler toplanmıştır. Görüşmelerde öğrencilerin fen alanındaki farkındalıkları tespit edilerek bilimsel yaratıcılık ve problem çözme konusunda öz değerlendirme yapmaları istenmiştir. Veriler içerik analizine göre analiz edilmiştir. Araştırma sonucunda öğrencilerin çoğunluğunun fen alanına karşı ilgili ve meraklı olduğu, kendilerini fen alanında üstün yetenekli gördüğü sonucuna ulaşılmıştır. Ayrıca öğrencilerin genel olarak zekâ ve yeteneklerinin farkında olduğu ve yüksek bir özgüven sergilediği görülürken bilimsel yaratıcılık ve bilimsel problem çözme konusunda aynı derecede özgüvene sahip olamadığı sonucuna ulaşılmıştır. Elde edilen çarpıcı sonuçlar eğitim sistemi ile ilişkilendirilerek irdelemeler yapılmıştır.

Anahtar Kelimeler: Bilimsel yaratıcılık, Bilimse problem çözme, Öz değerlendirme, Üstün yetenekli öğrenciler.

\footnotetext{
* Bu araştırma "Fen Alanında Üstün Yetenekli Öğrencilerin Tanılanmasına Yönelik Bir Model Geliştirme Önerisi” isimli doktora tezinin bir parçasıdır.

** Dr. Öğretim Üyesi, Mersin Üniversitesi, Eğitim Fakültesi, Matematik ve Fen Bilimleri Eğitimi Bölümü, Email:feride@mersin.edu.tr Orcid No: 0000-0003-1037-1473.

${ }^{* * *}$ Prof. Dr, Uludağ Üniversitesi, Eğitim Fakültesi, Matematik ve Fen Bilimleri Eğitimi Bölümü, Email:cepnisalih@yahoo.com Orcid No: 0000-0003-2343- 8796.

${ }^{* * * *} \mathrm{Bu}$ araştırma için Mersin Üniversitesi Sosyal ve Beşeri Bilimler Etik Kurul'undan 26/08/2020-36 say1lı etik izin alınmıştır.
} 


\title{
Self-Assessments of Gifted Students on Scientific Creativity and Scientific Problem Solving
}

\begin{abstract}
Gifted individuals play a key role in human progress due to their extraordinary potential led by their creativity and problem solving skills. The present research investigated gifted students' self-assessment on scientific creativity and scientific problem solving. This study was designed as a case study with a qualitative research approach. The study sample consisted of 21 gifted students at $6^{\text {th }}$ grade studying in Trabzon Science and Art Center. Data were collected from participating students through semi-structured interviews. Students' awareness in the field of science was identified during the interviews and they were asked to make self-assessments on scientific creativity and problem solving. The data were analyzed by content analysis. Research results demonstrated that the students were able to make definitions on their own and these definitions were in line with the literature. It was concluded that most of the participants were interested and curious about science and they regarded themselves to be gifted in science. In addition, it was determined that the students were generally aware of their intelligence and abilities and displayed high self-confidence but did not have the same level of self-confidence in scientific creativity and problem solving. The striking results obtained from the interviews were discussed in relation to the education system.
\end{abstract}

Keywords: Scientific creativity, Scientific problem solving, Self-assessment, Gifted students

\section{Giriş}

Geçmişten günümüze toplumların gelişimi incelendiğinde, onlara yön verenlerin, hatta çağları açıp kapayanların "pasif çoğunluk" değil; "aktif azınlık" olduğu görülmektedir (Watters ve Diezmann, 2003). Liderlik ve üretkenlik özelliğine sahip “üstün veya özel yetenekli kişiler” bahsedilen aktif azınlığı oluşturmaktadır (Çitil ve Ataman, 2018). Bu bağlamda üstün yetenekli öğrenciler gelecekte nitelikli ürünler verebilme potansiyeline sahip yeryüzü cevheri olarak tanımlanmaktadır (Orbay ve diğ., 2010; Şenol, 2011). Yukarıda her ne kadar üstün yetenekliliğe dair kısaca bir tanımlama yapılsa da alanyazında tek bir tanımın olmadığ1 söylenebilir. Hatta üstün yetenek mi, üstün zekâ mı, özel yetenek mi kavramının daha uygun olduğu bile tartışılmaktadır. Bu noktada Kaufman ve Sternberg (2008, s. 72) 
"araştırmacılar kendileri için hangi tanımların ve kavramların önemli olduğuna kendileri karar vermek durumundadırlar.” diyerek araştırmacının bir referans noktası belirlemesini tavsiye etmektedir. Alanyazındaki çoğu araştırmacı (Al-Hroub ve El Khoury, 2018; Gagne, 1985; Renzulli, 2005) tarafından üstün zekadan ziyade üstün yeteneklilik kavramının daha uygun olduğu ifade edilmektedir. Bu nedenle bu araştırmada da üstün yeteneklilik kavramı tercih edilmektedir.

Üstün yetenekli bireylerin eğitimi, içinde bulunduğumuz yüzyılda tüm dünyada ve ülkemizde önem arz etmektedir (Hadabi, 2010; Ülger ve Çepni, 2020). Hatta üstün yetenekli çocukların eğitimi bazı gelişmiş ülkelerde devlet politikası haline getirilmektedir (Cevher Kılıç, 2015; Shaughnessy ve Sak, 2013). Ülkemizde de söz konusu çocukların yetiştirilmesi için Millî Eğitim Bakanlığı (MEB) bünyesinde bulunan bilim sanat merkezlerinde yaratıcılık, problem çözme ve proje çalışmaları gibi bazı anahtar kavramlar ekseninde öğrencilerin potansiyellerinin geliştirilmesi amaçlanmaktadır (MEB, 2013).

\section{Üstün Yeteneklilik, Bilimsel Yaratıcılık ve Bilimsel Problem Çözme}

Gerek öğretim programları oluşturulurken gerekse alanyazında çalışmalar yapılırken üstün yeteneklilik problem çözme ve yaratıcılık kavramları birbiri ile ilişkili kavramlar olarak görülmektedir (Karabey ve Yürümezoğlu, 2015, Renzulli, 2002; Silvia, 2015). Nitekim alanyazında üstün yeteneklilik üzerine yetmişten fazla tanımın yapıldığı düşünülürse ve arama motorlarında 'üstün yeteneklilik, yaratıcılık ve problem çözme” üzerine arama yapıldığında 20 milyondan fazla sonuç çıktığı göz önüne alınırsa bahsedilen anahtar kavramların daha uzun yıllar çalışılabileceği söylenebilir. Üstelik bu ilişkili kavramların alt dallarının (örneğin alana özgü üstün yeteneklilik, bilimsel yaratıcılık ve bilimsel problem çözme) olduğu düşünülürse araştırmacılar için oldukça fazla çalışma konusu çıkabilmektedir (Kanl1, 2014). Örneğin “Üstün yetenekli olmak yaratıcı olmak için gerekli ve yeterli midir?”, "Bilimsel problem çözme ve bilimsel yaratıcık geliştirilebilir mi?", "Yaratıcılık genel mi yoksa alana özgü bir yetenek midir?” gibi sorular uzun yıllardır üzerinde çalışılan sorulardır (Andreasen, 2009). Örneğin Marie Curie kimya alanında keşifler yapmak yerine müzik ile ilgilenseydi Mozart gibi eserler bırakabilir miydi insanlığa? $\mathrm{Bu}$ sorunun cevabı yaratıcılı̆̆ın sınıflandırılması gerektiğini ve alana özgü yaratıcılığın önemli olduğunu göstermektedir (Kanlı, 2017; Kaufman ve Baer, 2004). Çoğu araştırmacı (Aktamış ve Ergin, 2006; Chamberlin ve Moon, 2005, Mohamed, Maker ve Lubart, 2012; Öz Aydın ve Ayverdi, 2014) yaratıcılığın alana özgü bir yetenek olduğunu dile getirmektedir. Çünkü yaratıcılık için 
k1smen bilgi gereklidir ve bilgi de belli bir alana özgü birikimdir (Mukhopadhyay ve Sen, 2013; Weisberg, 2006). Ayrıca burada yaratıcılığa giden yolda beslenilen kaynaklar da farklı olabilmektedir. Bu noktada söz konusu tanımlara çerçeve çizilirken sınırları belirleyen en önemli nokta elbette hangi tanımın temel alındığı ile ilgilidir. Örneğin Kim, Roh ve Cho (2016) fen alanındaki yaratıcılığı, kavramları işe koşarak eldeki problemleri yeni yöntemler ile çözebilme şeklinde tanımlamaktadır. Benzer şekilde Moravcsik (1981) bilimsel yaratıcılığı; bilimsel bilgiye eklenen yeni fikirlerin oluşumunda, teorileri formüle etmede, deney tasarlamada, pratik fikirleri bilimsel fikirleri geliştirmek için kullanmada, bilimsel plan ve projelerde orijinal işler ortaya koyabilme gibi beceriler olarak tanımlamaktadır. Feist (2006) bilimsel yaratıcılı̆̆ı; metafor ve analojilerden yararlanma, hipotez oluşturma, hipotezleri test etme, kanıt bulma, kompleks düşünme, bilimsel akıl yürütme ve yaratıcı problem çözme becerilerini kullanabilme becerileri ile ilişkilendirmektedir. Liang (2002) bilimsel yaratıcılığı ele alırken problem oluşturma, hipotez kurma ve fene karşı tutum gibi alt bileşenlerin olduğu bir tanımlama yapmaktadır. Hu ve Adey (2002) ise bilimsel yaratıcılığı problem bulma, ürün tasarlama ve objeleri çok amaçlı kullanma boyutlarına göre bir tanımlama yapmaktadır. Bazı tanımlarda görüldüğü gibi yaratıcılık problem çözme ile ilişkilendirilmektedir.

Alanyazında bilimsel problem çözme bir plan eşliğinde yapılan gözlem ve deneylere dayanarak sürdürülen çalışmaların tümü şeklinde tanımlanmaktadır. Demir (2018) ise “problem çözme fenin ta kendisidir.” ifadesi ile fenin ve bilimin merkezinde problem çözmenin yer aldığını belirtmektedir. Szybek (2002) de fen sayesinde günlük problemlerin bilimsel problemler haline getirilerek bilimsel düşünmenin gerçekleştiğini ifade etmektedir. $\mathrm{Bu}$ ifadelerden yola çıkarak bilimsel yaratıcılık ve problem çözme kavramlarının birbiri ile ilişkili kavramlar olduğu söylenebilir. Nitekim alanyazında söz konusu kavramları birlikte ele alan çalışmalar bulunmaktadır (DeHaan, 2009; Karaca, 2017; Treffinger ve Isaksen, 2005; Weisberg, 2006). Örneğin DeHaan (2009) çalışmasında yaratıcılık ile problem çözme ve diğer üst düzey bilişsel beceriler arasındaki ilişkiyi ele alarak söz konusu becerilerin nasıl geliştirilebileceğini incelemektedir. Akkanat (2019) da çalışmasında bilimsel yaratıcılık ve problem çözmenin gelişiminde motivasyon, okul ikilimi gibi faktörlerin yordama gücünü ele almaktadir.

Benzer şekilde üstün yeteneklilik ile bilimsel yaratıcılığı birlikte ele alan çalışmalar da alanyazında mevcuttur (Bıçakçı ve Baloğlu, 2018; Camcı Erdoğan, 2014; Hong, Heo, Lee, 2016; Hou, 2009; Kanl1, 2017; Kim ve Lim, 2019). Örneğin Kim ve Lim (2019) fende üstün 
yetenekli öğrencilerin bilimsel yaratıcılıklarını öz ve akran değerlendirme aracılığı ile karşılaştırmalı şekilde incelemektedir. Karademir (2016) tarafından yapılan çalışmada proje temelli etkinlikler ile üstün yetenekli öğrencilerin bilimsel yaratıcılıklarının belirlenmesini hedeflenmektedir. Bahsedilen çalışmalara ek olarak Cevher, Ertekin ve Köksal (2014) da çalışmalarında üstün yetenekli öğrencilerin bilimsel yaratıcılıklarını alt boyutlar ekseninde incelediğinde özgünlük boyutunda öğrencilerin yetersizliğini dile getirmektedir. Nuhoğlu ve Akgül (2019) de araştırmalarında üstün yetenekli öğrencilerin yaratıcılık ve bilimsel problem çözme becerilerini ele almaktadır. Üstün yeteneklilik ile yaratıcılık arasında yüksek bir korelasyon bulmayan araştırmacılar üstün yeteneklilerin problem çözme becerilerinin genel olarak yüksek olduğunu ifade etmektedir.

Yukarıdaki örneklerde yer aldığı gibi üstün yeteneklilik, bilimsel yaratıcılık ve problem çözme üçlüsündeki anahtar kavramları alanyazında çoğunlukla tek tek ya da ikili şekilde ele alan çalışmalar bulunmaktadır (Aktamış ve Ergin, 2006; Usta ve Akkanat, 2015). Söz konusu anahtar kavramların üçünü de aynı anda inceleyen araştırmaların sınırlı sayıda olduğu görülmektedir (Akkanat, 2019; Karabey, 2010; Wang ve diğ., 2019). Ayrıca sınırlı sayıda olan bu çalışmaların genellikle nicel araştırma yaklaşımına göre yapıldığı ifade edilebilir. Örneğin Kim ve Choi (2012) araştırmalarında bilim, teknoloji, mühendislik, sanat ve matematik (STEAM) eğitiminin üstün yetenekli öğrencilerin yaratıcılığını kullanarak problem çözme becerilerine nasıl etki ettiğini karşılaştırmalı bir şekilde incelemektedir. Benzer şekilde Kang ve Nam (2017) tasarım temelli mühendislik uygulamalarının üstün yetenekli öğrencilerin problem çözme becerilerine etkisini deneysel bir çalışmada araştırmaktadır.

\section{Üstün Yeteneklilik ve Öz Değerlendirme}

Üstün yetenekli öğrencilerin tanınmasında ve tanılanmasında genellikle kâğıt kalem testlerinden ve geleneksel ölçme değerlendirme yöntemlerinden yararlanılması söz konusudur. Bu noktadan hareketle üstün yetenekli öğrencilerin bilimsel yaratıcılık ve problem çözme becerilerini birlikte ele alan ve durumu derinlemesine incelemeye firsat veren öz değerlendirme niteliğinde çalışmalara ihtiyaç duyulduğu söylenebilir. Miller (1991) üstün yeteneklilerde öz değerlendirmenin önemini vurgulasa da alanyazında bu konuda sınırlı sayıda araştırma mevcuttur (Larroder \& Ogawa, 2015; Wirthwein ve diğ., 2019). Stenberg (2007) üstün yeteneklileri tanımada ve tanılamada kâğıt kalem testlerinden ziyade daha derin bilgiler ortaya koyabilen duygusal verilere ihtiyaç olduğunu savunmaktadır. McGinnis ve 
Kahn (2014) da Stenberg'i (2007) destekleyerek alana özgü yetenekleri ortaya çıkartırken aşina olunan nicel yöntemlerin dışına çıkılması gerektiğini önermektedir. Bu bağlamda öz değerlendirmenin üstün yeteneklileri tanımada ve onlarda farkındalık oluşturmada önemli bir veri toplama aracı olabileceğini söylemek mümkündür. Alanyazında üstün yeteneklilerde öz değerlendirme çalışmaları spesifik bir şekilde incelendiğinde bilimsel yaratıcılık ve problem çözme ile ilgili öz değerlendirme çalışmalarına rastlanmamıştır. Oysaki üstün yetenekli öğrencilerin katma değeri yüksek projeler gerçekleştirebilmeleri ve potansiyellerini ortaya koyabilmeleri için öncelikle kendi yeteneklerinin ve kimliklerinin farkına varabilmesi ve öz değerlendirme yapabilmeleri gerektiği düşünülmektedir. Bir diğer ifade ile üstün yeteneklilerin kendilerine yönelik farkındalıklarının oluşturulması gerektiğine inanılmaktadır. Bu amaçla mevcut araştırmada "Üstün yetenekli öğrencilerin bilimsel yaratıcılık ve bilimsel problem çözme konularında öz değerlendirmeleri nasıldır?” sorusuna cevap aranmaktadır. Bu amaç doğrultusunda gerçekleştirilen çalışmada aşağıda belirtilen alt araştırma sorularına da cevap aranması söz konusudur.

1- Üstün yetenekli öğrenciler fen alanındaki öz değerlendirmeleri nasıldır?

2- Üstün yetenekli öğrencilerin bilimsel yaratıcılıkta öz değerlendirmeleri nasıldır?

3- Üstün yetenekli öğrencilerin bilimsel problem çözmede öz değerlendirmeleri nasildir?

\section{Yöntem}

\section{Araştırmanın Deseni}

$\mathrm{Bu}$ araştırma, nitel araştırma yaklaşımlarının bir boyutu olan durum çalışmasına göre tasarlanmıştır. Bu desende, derinlemesine bilgi toplamak ve bütüncül bir şekilde durumu incelemek amaçlanır (Yıldırım ve Şimşek, 2016). Bu araştırmada üstün yetenekli öğrencilerin fen alanında, bilimsel yaratıcılık ve problem çözmede kendilerine dair öz değerlendirmeleri irdelendiği için araştırmanın durum çalışmasına uygun olduğu düşünülmüştür.

\section{Katılımcılar/Örneklem/Çalıșma Grubu}

Bu araştırma Trabzon Bilim Sanat Merkezi’nde 6. sınıf düzeyinde öğrenim gören yedi kız ve on dört erkek olmak üzere yirmi bir öğrenci ile yürütülmüştür. Araştırmada kolay ulaşılabilir örnekleme yöntemine göre veriler toplanmıştır. Katılımcılar araştırmaya dahil edilmesinde gönüllülük esası göz önünde bulundurulmuştur. Tablo 1'de katılımcı bilgileri mevcuttur. 
Tablo 1. Araştırmaya Katılan Üstün Yetenekli Öğrencilere Yönelik Demografik Bilgiler

\begin{tabular}{llll}
\hline $\begin{array}{l}\text { Öğrenci } \\
\text { kodları }\end{array}$ & Öğrenci cinsiyeti & \multicolumn{1}{c}{ Öğrencinin Okulu } & $\begin{array}{l}\text { Bilim Sanat Merkezinde Aldığ } \\
\text { Eğitim /Alan }\end{array}$ \\
\hline Öğrenci 1 & Kız & Devlet okulu (A) / İlçe & Fen, Müzik, Resim \\
Öğrenci 2 & Kız & Devlet okulu (B) / Trabzon il merkezi & Resim, Matematik \\
Öğrenci 3 & Erkek & Devlet okulu (C) / İlçe & Fen, Müzik \\
Öğrenci 4 & Erkek & Devlet okulu (B) / Trabzon il merkezi & Müzik, Türkçe \\
Öğrenci 5 & Kız & Devlet okulu (A) / İlçe & Resim, Türkçe \\
Öğrenci 6 & Erkek & Devlet okulu (B) / Trabzon il merkezi & Türkçe, Fen \\
Öğrenci 7 & Erkek & Devlet okulu (D) / Trabzon il merkezi & Matematik \\
Öğrenci 8 & Kız & Devlet okulu (E) / Trabzon il merkezi & Resim, Fen \\
Öğrenci 9 & Kız & Devlet okulu (D) / Trabzon il merkezi & Matematik, Müzik \\
Öğrenci 10 & Erkek & Devlet okulu (F) / Trabzon il merkezi & Müzik, Fen \\
Öğrenci 11 & Erkek & Devlet okulu (D) / Trabzon il merkezi & Türkçe, Fen \\
Öğrenci 12 & Erkek & Özel okul (G) / Trabzon il merkezi & Matematik, Resim \\
Öğrenci 13 & Erkek & Devlet okulu (H) / İlçe & Matematik, Fen \\
Öğrenci 14 & Kız & Devlet okulu (B) / Trabzon il merkezi & Matematik, Resim \\
Öğrenci 15 & Erkek & Devlet okulu (B) / Trabzon il merkezi & Fen \\
Öğrenci 16 & Erkek & Devlet okulu (I) / Trabzon il merkezi & Matematik, Fen \\
Öğrenci 17 & Kız & Devlet okulu (J) / Trabzon il merkezi & Matematik, Fen \\
Öğrenci 18 & Erkek & Devlet okulu (K) / İlçe & Matematik, Fen \\
Öğrenci 19 & Erkek & Devlet okulu (B) / Trabzon il merkezi & Matematik, Resim \\
Öğrenci 20 & Erkek & Devlet okulu (B)/ Trabzon il merkezi & Resim, Fen \\
Öğrenci 21 & Erkek & Devlet okulu (L) / Trabzon il merkezi & Resim, Fen \\
\hline
\end{tabular}

Çalışmada yer alan öğrencilerin çoğunluğunun erkek öğrenci olduğu görülmektedir. Okul türü sütunundaki harfler öğrencilerin devam ettiği okulu göstermektedir. Bu bağlamda öğrencilerin büyük çoğunluğunun devlet okullarında eğitim aldığı ve birçok farklı devlet okulunda öğrenim gördüğü söylenebilir. Tabloya göre bilim sanat merkezine devam eden öğrenciler arasında on altı öğrenci Trabzon il merkezindeki okullarda öğrenim görürken beş öğrenci Trabzon'un ilçelerinde öğrenim görmektedir. Öğrencilerin bilim sanat merkezinde aldığı öğrenim alanları incelendiğinde çoğunun fen alanında öğrenim gördüğü söylenebilir. Ayrıca resim, müzik, matematik ve Türkçe alanlarında da öğrenim gören katılımcılar bulunmaktadir.

Araştırmada yer alan katılımcı bilgilerini ayrıntılı bir şekilde sunabilmek adına öncelikle bilim sanat merkezlerindeki eğitim programlarından kısaca bahsedilmesinin uygun 
olacağ1 düşünülmektedir. Bilim sanat merkezinde öğrenim görmeye hak kazanan öğrenciler beş aşamalı bir eğitim programı ile karşılaşmaktadır. Bu aşamalar oryantasyon (uyum) programı, destek eğitim programı, bireysel yetenekleri fark ettirme programı, özel yetenekleri geliştirme programı ve proje üretimi/yönetimi programı şeklinde sıralanabilir. Bu araştırmaya dahil olan üstün yetenekli öğrencilerin bireysel yetenekleri fark ettirme programına kayıtlı olduğu söylenebilir. Bu sebeple öğrencilerin kendi potansiyellerini keşfetmeye başladığ bir dönemde araştırma verilerinin toplanması söz konusudur.

\section{Veri Toplama Aracı}

$\mathrm{Bu}$ çalışmada, öğrencilerin bilimsel yaratıcılık ve bilimsel problem çözme konusundaki görüşlerinin bir öz değerlendirme olarak ortaya çıkarılması amaçlanmaktadır. $\mathrm{Bu}$ sebeple nitel veri toplama tekniklerinden yarı yapılandırılmış mülakat kullanılmıştır. Katılımcılara dört soru sorularak görüşleri alınmıştır. Aşağıda araştırma kapsamında sorulan sorular sunulmuştur.

1- Genel olarak zekâ ve yetenek konusunda kendinizi nasıl görüyorsunuz?

2- Fen alanında kendinizi nasıl görüyorsunuz?

3- Bilimsel yaratıcılık konusunda kendinizi nasıl buluyorsunuz?

4- Bilimsel problemleri çözmede kendinizi nasıl buluyorsunuz?

Hazırlanan yarı yapılandırılmış mülakat soruları dört uzman (fen eğitimi alanında öğretim üyesi) görüşüne sunulmuştur. Uzman görüşü sonrasında gerekli düzenlemeler yapılarak görüşme sorularına son hali verilmiştir. Soruların amacına hizmet edip etmediğini test edebilmek amacıyla Bartın Bilim ve Sanat Merkezi'nde öğrenim gören on sekiz öğrenci ile pilot uygulama yapılmıştır. Pilot uygulama sonucunda soruların dil ve anlam açısından sıkıntı teşkil etmediği tespit edilmiştir.

\section{Verilerin Analizi}

Yarı yapılandırılmış mülakatlardan elde edilen verilerin analizi içerik analizine göre yapılmıştır. İçerik analizinde temel amaç, toplanan verileri açıklayabilecek kavramlara ve ilişkilere ulaşmaktır (Miles ve Huberman, 1994). Analiz süreci için öncelikle katılımcılardan elde edilen mülakat verileri dijital ortama kaydedilerek yazılı hale getirilmiştir. Ardından her bir katılımcının mülakatlarda verdiği cevaplar tekrar tekrar okunarak araştırma kapsamı dışında kalan veriler çıkartılmış ve veriler indirgenmiştir. İki araştırmacı gerek kodların oluşturulması sürecinde gerekse diğer analiz sürecinde birbirlerini etkilememek adına ilk 
etapta birbirinden bağımsız çalışmışlardır. Daha sonra iki araştırmacının analiz sürecinde uyuşamadığı noktalar pek olmamakla birlikte mevcut farklı kodlamalarda, üzerinde tartışmalar yapılarak birlikte karar verilmiştir ve uzlaşma sağlanmıştır. Hem içerik analizinin hem de bulguların daha anlaşılır olabilmesi için Tablo 2'de analiz sürecinde oluşturulan kodlar ve temalar sunulmuştur.

Tablo 2. Öğrenci Mülakatlarından Elde Edilen Tema ve Kod Örnekleri

\begin{tabular}{|c|c|c|c|}
\hline Tema & Kod & Alt kod & Katılımcı görüşü \\
\hline \multirow{3}{*}{$\begin{array}{l}\text { Zekâ Öz } \\
\text { değerlendirme }\end{array}$} & $\begin{array}{l}\text { Zeki olduğunu } \\
\text { düşünme }\end{array}$ & Bilim sanat merkezi & $\begin{array}{l}\text { Açıkçası bilim sanat merkezini kazandığım } \\
\text { için zeki olduğumu düşünüyorum. (Öıl) }\end{array}$ \\
\hline & $\begin{array}{l}\text { Kısmen zeki } \\
\text { olduğunu düşünme }\end{array}$ & $\begin{array}{l}\text { Alana bağlı } \\
\text { Sıradanlık }\end{array}$ & $\begin{array}{l}\text { Sorulan alana göre bu sorunun cevabı } \\
\text { değişir. Bir alanda zeki olabilen biri başka } \\
\text { bir alanda sıradan biri olabilir. (Ö14) }\end{array}$ \\
\hline & $\begin{array}{l}\text { Zeki olmadığını } \\
\text { düşünme }\end{array}$ & Bireysel tanımlama & $\begin{array}{l}\text { Kendimi zeki görmüyorum. Benim zekâ } \\
\text { tanımıma göre zekâ aklını kullanmaktır ve } \\
\text { ben aklını kullanan biri değilim. (Ö11) }\end{array}$ \\
\hline \multirow{3}{*}{$\begin{array}{l}\text { Fen Alanında Öz } \\
\text { değerlendirme }\end{array}$} & $\begin{array}{l}\text { Üstün yetenekli } \\
\text { olduğunu düşünme }\end{array}$ & $\begin{array}{l}\text { İlgi ve merak } \\
\text { Araştırma } \\
\text { Bilimsel metin }\end{array}$ & $\begin{array}{l}\text { Fen alanında kendimi iyi görüyorum. } \\
\text { Fenden hoşlanırım. Mesela belgesel izlemek } \\
\text { ya da bilimle ilgili şeyleri okumak, ilgimi } \\
\text { çeker. (Ö2) }\end{array}$ \\
\hline & $\begin{array}{l}\text { Kismen üstün } \\
\text { yetenekli olduğunu } \\
\text { düşünme }\end{array}$ & $\begin{array}{l}\text { okuma } \\
\text { Siradanlık }\end{array}$ & $\begin{array}{l}\text { Fende sıradan biriyim. Ekstra bir şeyler } \\
\text { olduğunu düşünmüyorum. (Ö8) }\end{array}$ \\
\hline & $\begin{array}{l}\text { Yeteneksiz } \\
\text { olduğunu düşünme }\end{array}$ & & $\begin{array}{l}\text { Fende yetenekli olduğumu düşünmüyorum. } \\
\text { Herkes kadar görüyorum kendimi fazladan } \\
\text { becerim ya da ilgim yok (Ö5) }\end{array}$ \\
\hline \multirow{6}{*}{$\begin{array}{l}\text { Bilimsel } \\
\text { Yaratıcılıkta Öz } \\
\text { değerlendirme }\end{array}$} & Üst düzey & Orjinallik & $\begin{array}{l}\text { Farklı fikirler ve hipotezler üretebiliyorum. } \\
\text { Meraklı ve araştırmacıyı. (Ö11) }\end{array}$ \\
\hline & & Deney tasarlama & \\
\hline & Orta düzey & & Sira dışı şeyler üretemem. (Ö4) \\
\hline & & Siradanlık & $\begin{array}{l}\text { Aklıma yaratıcı fikirler gelse de okuldan ve } \\
\text { zamansılıktan dolayı uygulamaya }\end{array}$ \\
\hline & & Zamansızlık & geçemiyorum. (Ö10) \\
\hline & Düşük düzey & Eğitim sistemi & $\begin{array}{l}\text { Derslerde ögretmenimden farklı çözümler } \\
\text { üretiyorum ve tepki topluyorum. (Ö20) }\end{array}$ \\
\hline
\end{tabular}




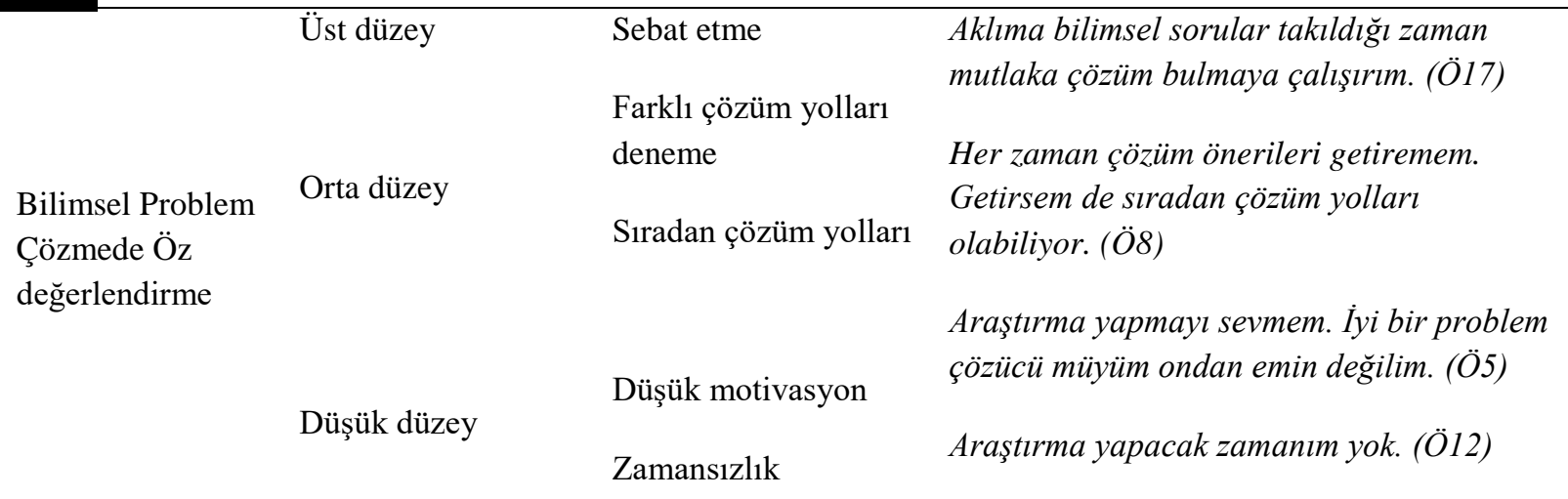

Kodlama sonucunda veriler şekil, matris ve alıntılar yardımıyla sunulmuştur. Kodlamaların frekansını her defasında tablolar halinde vermek yerine frekanslar görselde parantez içinde yazılmıştır. Ayrıca verilerin inandırıcılığını arttırması amacıyla katılımcıların mülakatlarda verdiği sıra dışı ya da konu ile ilgili örnekler alıntı halinde sunulmasının yararlı olacağı düşünülmüştür. Cohen'in Kappa uyum katsayısı belirlenmiştir. Dawson Saunder ve Trap (2004) nitel veri analizinde .61 üzerindeki uyum katsayısının kabul edilebileceğini ve yoruma bağlı farklılık olmakla birlikte kabul edilebileceğini belirtmektedir. Ayrıca .61 ile .80 arasındaki uyumun güçlü uyum sayılabileceği de ifade edilmektedir. Bu araştırmada nitel verilerin genel analizi sonucunda Cohen'in Kappa uyum katsayıs1 0,93 olarak tespit edilmiştir. Kodlara ve temalara göre organize edilen veriler matrisler ve şekiller yardımıyla sergilenmiştir. Matrisler ve diğer görseller çalışmayı betimleyen aydınlatıcı bilgiler sunarken verileri somutlaştırma noktasında da oldukça uygun bir çözümleme formatıdır (Miles ve Huberman, 1994). Araştırmada doğrulanabilirliğin sağlanması için işlenmemiş veriler, bulgular, yorum ve öneriler kayıt altına alınarak tekrar tekrar denetlenmiştir. Geçerliğin, güvenirliğin ve doğrulanabilirliğin arttırılması için ayrıca araştırmacının öznel varsayımlarına ya da (varsa) verileri yanlış anlamasına sebebiyet verilmemesi adına katılımcı teyidine de başvurulmuştur. Katılımcı teyidinde araştırmacı verileri katılımcıya sunarak toplanan verilerin doğruluğuna ilişkin düşüncelerini belirtmelerini istemiştir. Yapılan araştırmada inandırılabilirlik ve aktarılabilirliğin sağlanabilmesi için araştırma süreci okuyucuya detaylı olarak açıklanmaya çalışılmıştır.

Araştırmada bireysel ve kurumsal mahremiyete dikkat edilmiş ve araştırma etiği çerçevesinde okul ve katılımcıların isimleri kullanılmamıştır. Okul isimleri “A, B, C vb.” şeklinde isimlendirilirken katılımcılar için $\ddot{O}_{1}, \mathrm{O}_{2}$ gibi kodlar kullanılmıştır. 


\section{Etik Kurul Kararı}

$\mathrm{Bu}$ araştırma için Mersin Üniversitesi Sosyal ve Beşerî Bilimler Etik Kurul'undan 26/08/2020-36 sayılı etik izin alınmıştır.

\section{Bulgular}

Görüşmelerde öncelikle öğrencilerin zekâ ve üstün yeteneklilik konusunda genel bir değerlendirme yapması istenmiş ardından fen alanındaki öz değerlendirmelere geçilmiştir. Daha sonra bilimsel yaratıcılık ile ilgili değerlendirme yapmaları istenmiş ve son olarak da bilimsel problem çözme alanında öz değerlendirme yapmaları istenmiştir. Bu bağlamda bulguların üç başlık altında sunulmasının daha anlamlı olacağı düşünülmüştür.

\section{Fen Alanına Yönelik Öz Değerlendirme Bulguları}

Öğrencilerin zekâ konusundaki genel değerlendirmeleri Şekil 1'de sunulmuştur.

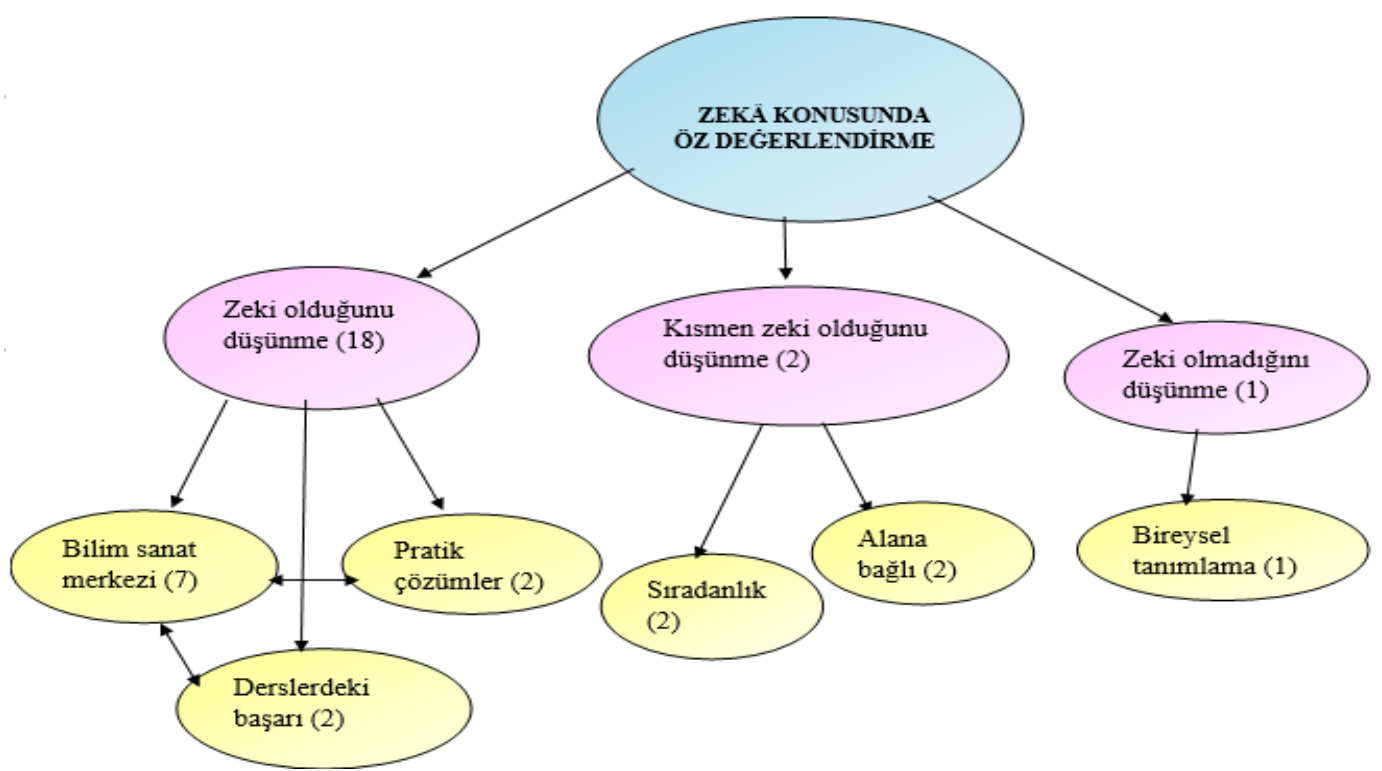

Şekil 1. Öğrencilerin Zeka Konusundaki Öz Değerlendirmeleri

Şekil 1 incelendiğinde öğrencilerin büyük çoğunluğunun kendilerini zeki bulduğu görülmektedir. Kendini zeki gören on sekiz kişilik öğrenci grubundaki yedi kişi bilim sanat merkezi sınavlarını kazanmayı en büyük kanıt olarak göstermektedir. Bu konuda görüş beyan eden öğrencilerden Ö${ }_{1}$ kodlu öğrenci; "Kendimi zeki buluyorum. Açıkçası Bilim sanat merkezini kazandiğım için zeki olduğumu düşünüyorum.” ifadeleri ile bu konudaki özgüvenini sergilemiştir. Bilim sanat merkezine gelmenin yanında derslerinde başarılı olduğu için ya da pratik çözümler sunabildiği için kendisini zeki hisseden öğrenciler de bulunmaktadır. Bu 
görüşte olan öğrencilerden Ö 13 kodlu öğrenci “Ben kendimi zeki buluyorum. Neden mi? Çünkü bunun bir sürü kanıtı var şu anda yani burada bilim sanat merkezinde sizle oturup mülakat yapmam bile bunun bir açılkaması olabilir. Ayrlca derslerde de bunun belirtisi oluyor. Derslerim çoğu arkadaşımdan daha iyi mesela." cümleleri ile görüşlerini yansıtmıştır. Ö kodlu öğrenci de “Diğer insanlardan farklı olduğumu düşünüyorum. Çünkü onlardan farklı olmasaydım bilim sanat merkezine gelemezdim. Ayrıca zekâ konusunda pratik çözümlerim var.” ifadeleri ile bu konudaki görüşünü dile getirmiştir.

Zekâ konusunda kendisini üstün görmeyen iki öğrenci bulunmaktadır. Bu öğrenciler kendilerini diğer insanlar gibi görerek orta seviyede (standardın altında ya da üstünde değil) gördüğünü ve sıra dışı olmadığını ifade etmiştir. Bu konuda Ö$_{14}$ kodlu öğrenci görüşlerini dile getirirken "Ben kendimi zekâ konusunda normal buluyorum. Herkeste olduğu kadardır, normal yani. Çünkü çoğu kişiyle aynı şekilde düşünüyorum sorulara aynı şekilde yanıt veriyorum, aynı yoldan çözüyorum.” cümlelerini kullanmıştır. Yirmi bir kişi ile yapılan mülakatlarda bir öğrenci kendisini zeki bulmadığını ifade etmiştir. Ö konusunda düşük bir özgüven sergileyerek "Bana göre zekâ aklı kullanmaktır. Bu sebeple zekâ ilgili söylediklerime göre ben zeki değilim. Ben aklımı kullandiğımı düşünmüyorum. Bu tanımıma göre zeki değilim.” İfadelerini kullanmıştır.

Öğrencilere fen alanında kendilerini üstün yetenekli görüp görmedikleri sorulduğunda Şekil 2'deki sonuçlar ortaya çıkmıştır.

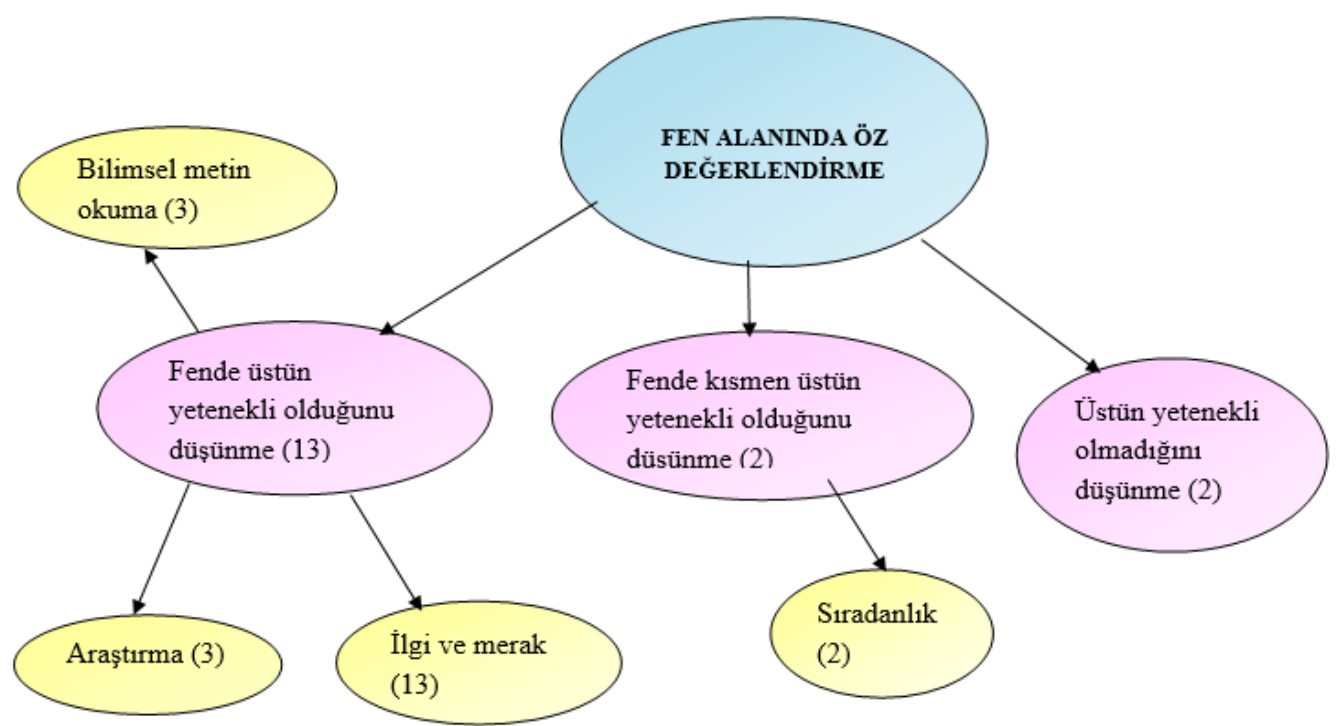

Şekil 2. Öğrencilerin Fen Alanındaki Öz Değerlendirmeleri

Yirmi bir öğrenci ile yapılan görüşmelerde on beş öğrenci fen alanında kendisini üstün yetenekli görmektedir. Fende üstün yetenekli olduğunu düşünen bazı öğrenci cümleleri 
alıntılar şeklinde sunulmuştur. Örneğin Ö 4 kodlu öğrenci “Fen alanında iyiyim bence. Gözlem yapabiliyorum, sonuçlar çıkarıp kendimce veriler toplayabiliyorum ki onlar da önemli bence... Bilim insanlarındaki çoğu özellik var bende diye düşünüyorum. Örneğin gözlem yapabiliyorum, meraklıyım. Verileri toplayıp sonuç çıkarabiliyorum ya da deney de tasarlayabiliyorum. O yüzden iyi olduğumu düşünüyorum.” cümleleri ile fen alanında üstün yetenekli olduğunu ifade etmiştir.

Çalışma grubunda yer alan iki öğrenci fen alanında kısmen yetenekli olduğunu düşünmektedir. Diğer bir ifade ile bu öğrenciler fende sıra dışı olmadığını, normal bir bireyin fen alanında gösterdiği beceriler kadar beceri gösterdiğini belirtmiştir. Bahsedilen öğrencilerden Ö8 kodlu öğrenci "Fen alanında bazen kendimi yetenekli buluyorum bazen herkes gibi görüyorum.” diyerek kendisi için özeleştiride bulunmuştur. Araştırmada yer alan iki öğrenci ise fen alanında yetenekli olmadığını düşünmektedir. Bu konuda Ö${ }_{5}$ kodlu öğrenci “Fen alanında yetenekli olduğumu düşünmüyorum. Aklıma bilimsel bir soru falan geldiğinde ilgilenip araştırayım demiyorum.” ifadeleri ile fen alanında üstün yetenekli olmadığını belirtmiştir.

Mülakat yapılan öğrencilerin birkaçı ise fende üstün yetenekli olma ya da olmama durumuna değinmeksizin sadece fen ile ilgili duygu ve görüşlerini dile getirmiştir. Örneğin on üç öğrenci ilgi ve merak içeren cümleler kurmuş feni sevdiğini beyan etmiştir. Üç öğrenci fene olan ilgisini anlatırken okul dışında yani herhangi bir ödev olarak verilmeksizin bir konu üzerinde araştırma yapabildiğine vurgu yapmıştır. Yine bir diğer üç öğrenci fen dersi dışında da bilimsel şeyler okumayı ve izlemeyi sevdiğini ifade etmiştir. Önceki cümlelerde bahsedilen görüşlere örnek teşkil etmesi bakımından bazı öğrenci cümlelerinden alıntılar sunulmuştur. Örneğin Ö 21 kodlu öğrenci “Fen alanında kendimi istekli görüyorum kendimi. Seviyorum feni." ifadelerini kullanırken $\ddot{O}_{13}$ kodlu öğrenci “Fen alanında araştırmalar yapmayı seviyorum. Kendi kendime düşünüyorum mesela bu nasıl olabilir acaba diye. 5N1K yöntemini kullanıyorum çoğunlukla bunların sebeplerini sonuçlarını araştırmaya çalışıyorum elimden geldiğince.” ifadelerini kullanmıştır. Bu noktada bir öğrencinin sıra dışı cevabı düşündürücü bir bulgu olarak karşımıza çıkmaktadır. Ö 12 kodlu öğrenci “Fene karşı sevgim hem evettir hem hayır. Ders anlamındaki feni sevmiyorum ama branş olarak feni seviyorum. Çünkü dersler çok sıkıcı oluyor. Ancak okul dışında aklıma bilimsel bir şeyler takıldı̆̆ında ya da fen ile ilgili araştırmalar yaptığımda ilgi duyacak kadar da feni seviyorum. Bu durumda ders anlamındaki fen ile branş anlamındaki fen bence farklı şeyler." ifadeleri ile çarpıcı bir yorumda bulunmuştur. Bu noktada öğrencinin ders ve branş anlamındaki fenin ayrımına 
varması dikkat çekici bir durumdur. Aynı zamanda fene ilgili olması sevindirici bir durum iken okullarda gösterilen fen derslerini sıkıcı bulması ise olumsuz bir durumdur. Bu durum üstün yetenekli öğrencilerin öğretim programında yer alan fen derslerini nasıl algıladığı ve sıkıcı bulup bulmadığ 1 sorusunu akla getirmektedir.

Öğrencilerin fen alanına yönelik öz değerlendirmeleri sonucunda öğrencilerin çoğunlukla fen alanında kendilerini üstün yetenekli olarak gördüğü ve fene yönelik olumlu görüş içinde olduğu söylenebilir. Ayrıca öğrencilerin fen alanında mevcut potansiyellerinin farkında olduğu ifade edilebilir.

\section{Bilimsel Yaratıcılığa Yönelik Öz Değerlendirme Bulguları}

Bulguların bu kısmında öğrencilerin bilimsel yaratıcılık noktasında kendilerine yönelik öz değerlendirmeleri ele alınmıştır. Öncelikle görüşmede bilimsel yaratıcılık kavramı öğrencilere açıklanmıştır. İlgili örnekler verildikten sonra kendilerinin bilimsel yaratıcılıklarını eleştirel bir gözle incelemeleri istenmiştir. Elde edilen bulguları ayrıntılı bir şekilde sunabilmek adına bulgular matris şeklinde aşağıda sunulmuştur.

Matris 1. Öğrencilerin Bilimsel Yaratıcılık Konusundaki Öz Değerlendirmeleri

\begin{tabular}{|c|c|c|c|c|}
\hline & Üst düzey & Orta düzey & Düşük düzey & Gerekçesi \\
\hline Ö1 & $\mathrm{X}$ & & & $\begin{array}{l}\text { Farklı fikirler ve hipotezler üretebilirim. Deney } \\
\text { tasarlayabilirim. }\end{array}$ \\
\hline Ö2 & & $\mathrm{X}$ & & Problemlere farklı çözüm önerileri getirebilirim \\
\hline Ö3 & & & $\mathrm{X}$ & ------ \\
\hline Ö4 & & & $\mathrm{X}$ & Sıradışı şeyler üretemem \\
\hline Ö5 & --- & --- & --- & --- \\
\hline Ö6 & & $\mathrm{X}$ & & --- \\
\hline Ö7 & & $\mathrm{X}$ & & $\begin{array}{l}\text { Deney tasarlayabilirim ve farklı çözüm önerileri } \\
\text { getirebilirim }\end{array}$ \\
\hline Ö8 & & $\mathrm{X}$ & & --- \\
\hline Ö9 & & $\mathrm{X}$ & & $\begin{array}{l}\text { Bazen herkes gibi oluyorum. Bazen sıra dışı } \\
\text { düşünebilirim. }\end{array}$ \\
\hline Ö10 & & $\mathrm{X}$ & & Yaratıcı olmak için zamanım yok. \\
\hline Ö11 & $X$ & & & $\begin{array}{l}\text { Farklı fikirler ve hipotezler üretebiliyorum. Meraklı } \\
\text { ve araştırmacıyım }\end{array}$ \\
\hline
\end{tabular}


$\mathrm{X}$

Farklı deneyler tasarlayamam ama birden fazla öneri getirebilirim.

Ö13

X

Ö14 X

Ö15 X

Ö16

Ö17 X

Ö18

Ö19

Ö20

Ö21
X

X

X

$\mathrm{X}$
Deney tasarlayabilirim.

Farklı fikirler kısmen üretebilirim

Farklı fikirler üretebilirim

Bilimsel yaratıcılığa yönelik öğrenci görüşlerinin yer aldığı matris incelendiğinde iki (Ö${ }_{5}$ ve $\ddot{O}_{21}$ ) öğrencinin görüşmelerin bu kısmında fikir beyan etmediği görülmektedir. Fikir beyan eden öğrenciler arasından beş öğrenci özgüveni yüksek bir tavır sergileyerek bilimsel yaratıcılıkta kendisini üst düzeyde görmektedir. Bu kategoride yer alan öğrencilerden $\mathrm{O}_{1}$ kodlu öğrenci “Bilimsel yaratıcılı̆̆ımın iyi olduğunu düşünüyorum. Örneğin iyi deneyler tasarlayabiliyorum. Daha değişik fikirler bulabiliyorum.” diyerek ve Ö 11 kodlu öğrenci "Yaratıcı buluyorum kendimi. Çünkü sıradışı hipotezler öne sürebiliyorum. Birçok insanın aklına gelmeyecek sonuçlar çıkarabiliyorum. Meraklıyım, araştırmacıyım o yüzden bence iyiyim.” ifadelerini kullanarak görüş bildirmişlerdir. Katılımcılardan on bir öğrenci bilimsel yaratıcılıkta kendisini orta düzeyde (kısmen yeterli) görmektedir. Bu grupta yer alan üç öğrenci açıklayıcı bir neden belirtmez iken yedi öğrenci yaratıcılığın bazı boyutlarında kendilerini başarılı bulup bazı boyutlarında başarılı bulamamaktadır. Bu sebeple öğrenciler kısmi bir yeterlilikten bahsetmektedirler. Bu konuda $\mathrm{O}_{2}$ kodlu öğrenci “Bilimsel anlamda çok yaratıcı değilimdir. Yaratıcılı̆̆ım iyi değildir. Yaratıcılık ve problem çözmede kendimi normal görüyorum ama zekâ konusunda kendimi biraz daha üst düzey görebiliyorum.” ifadelerini kullanmıştır.

Öğrencilerin bazıları genel anlamda kastedilen yaratıcılıkta kendilerini üst düzeyde (yeterli) görürken bilimsel yaratıcılık konusunda kendilerini aynı şekilde yeterli görememektedir. $\mathrm{Bu}$ bağlamda bilimsel yaratıcılık konusunda bazı öğrencilerde genel yaratıcılık ya da zekâ konusunda olduğu kadar özgüvenden bahsedilememektedir. Bu görüşte 
olan $\mathrm{Ö}_{20}$ kodlu öğrenci "Yaratıcıllkta genel olarak iyi olduğumu düşünüyorum. Yaratıcı birisiyim. Bilimsel yaratıcılıkta o kadar olmasa da kısmen iyiyim.” cümleleri ile düşüncelerini belirtmiştir. Üç öğrenci de bilimsel yaratıcılıkta kendisine yönelik olumsuz düşünceler içindedir. Bu öğrencilerden iki tanesi açıklayıcı nedenler belirtmezken bir tanesi klasik düşüncelerden kurtulamadığını ve sıra dışı fikirler üretmediğini belirtmiştir.

Çalışmanın bilimsel yaratıcılık boyutu araştırılırken öğrencilerin genel görüş ve tespitleri incelenmiştir. Ancak araştırmacının mülakatlarda ilginç diyaloglar ile karşılaştığ durumlar da olmuştur. Önemli veriler olması sebebiyle bu bulgular da çalışmaya dahil edilmiştir. Ancak daha önce bahsedilen bulgulara entegre edilemediğinden sıra dışı tespitlerin yer aldığı bulguların ayrı bir kategoride sunulması gerektiği düşünülmüştür. Bilimsel yaratıcılık kapsamında geçen bazı diyaloglar Şekil 3’te görsel bir şekilde sunulmuştur.

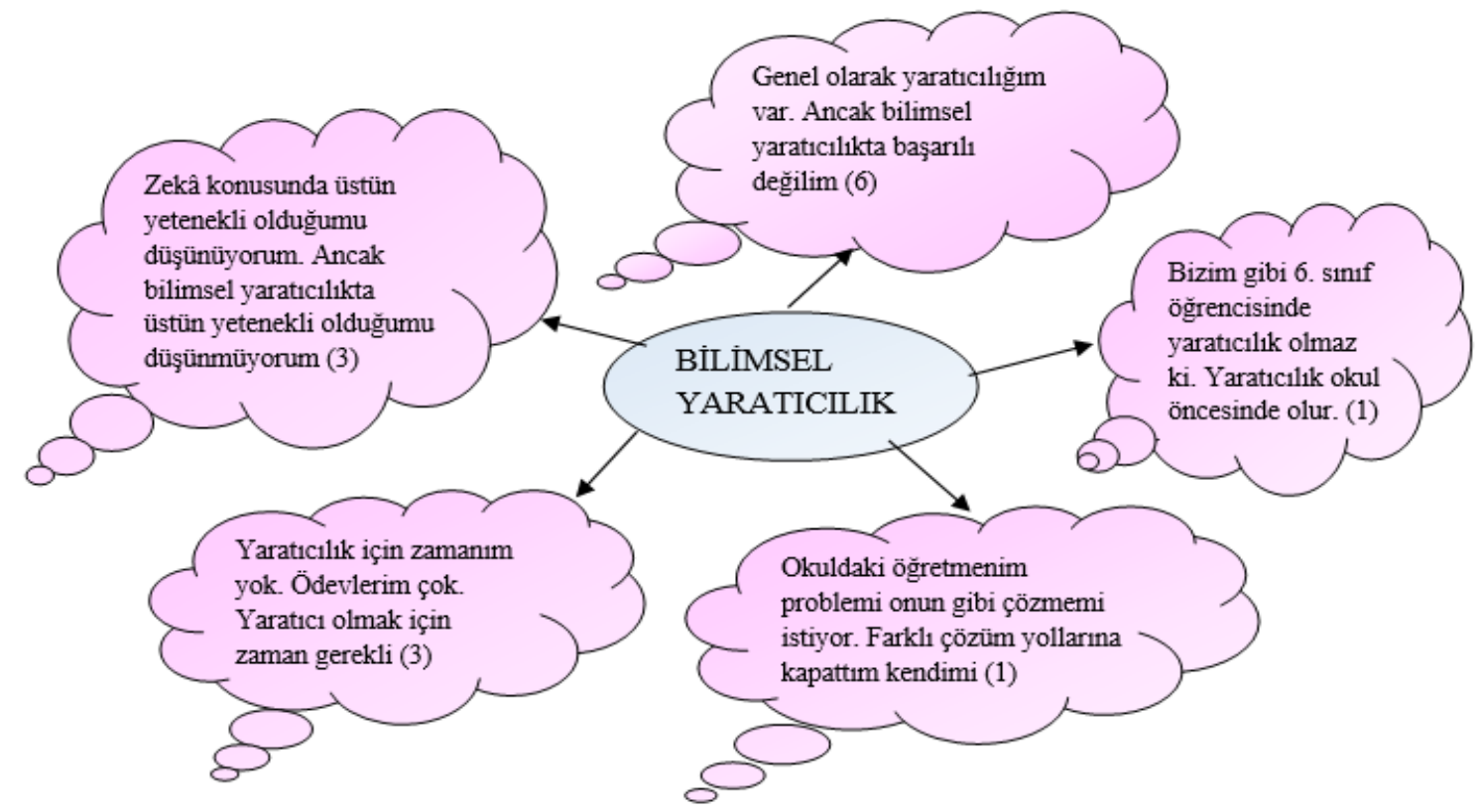

Şekil 3. Bilimsel Yaratıcılık Konusundaki Sıra Dışı Değerlendirme ve Tespitler

Şekil 3’te yer alan cümleler incelendiğinde çoğunun olumsuz bulgu niteliğinde olduğu söylenebilir. Bazı cümlelerin altı bazılarının üç kişi tarafından söylendiği düşünülürse bu görüşlerin bireysel görüş olmaktan çıkıp mevcut sorunları yansıtan görüşler olduğunu söylemek mümkündür. Öğrenci görüşlerinin daha iyi anlaşılabilmesi için mülakattan ayrıntılı bir şekilde alıntılar yapılmıştır. Örneğin Ög kodlu öğrenci “Yaratıcı ve üretken olduğum söylenebilir. Ancak zekâ konusunda üç aşama üstteysem bilimsel yaratıcılıkta bir aşama üsteyimdir denebilir.” ifadelerini kullanırken $\mathrm{Ö}_{10}$ kodlu öğrenci “Yaratıcık için çok zamanım yok. Çünkü aklıma bir soru ya da fikir geldiğinde ertesi güne yetiştirmem gereken bir projem, performans ödevim, özel dersim vb. mutlaka oluyor. Ben de ödevlerime yani kendi 
yoğunluğuma dönmek zorunda kallyorum. Bu yoğunluklarım olmasa daha yaratıcl olabilirim.” ifadelerini kullanmıştır. Ayrıca Ö 11 kodlu öğrencinin de sıra dışı tespitleri “Öğretmenim ders içinde farklı çözüm yollarımı söylediğimde hiç sıcak bakmıyor. Birkaç kez sınavlarda da farklı çözüm yollarını denedim ama öğretmenim gibi çözmediğim için puan alamadım. Şimdi sınavlarda ögretmenim gibi çözüyorum. Yaratıcılı̆̆ım varsa bile okulda göstermiyorum. Derste de farklı fikirlerim olsa bile söylemiyorum.” cümlelerinde görülmektedir. Bir diğer farklı tespit ise $\mathrm{O}_{7}$ kodlu öğrenci tarafından belirtilmiştir. Bahsedilen öğrenci "Yaratıcılık dediğimiz hayal dünyasının okul öncesi dönemde olduğunu düşünüyorum. İlkögretim 6. sınıf öğrencisinde yaratıcılık kalmaz ki. Derslerimiz zaten yaratıcı olmaya uygun değil” cümleleri ile eğitim sistemine atıfta bulunmuştur.

\section{Bilimsel Problem Çözmeye Yönelik Öz Değerlendirme Bulguları}

Öğrencilerin bilimsel problem çözmeye yönelik öz değerlendirmeleri de mülakatlarda incelenmiştir. Mülakatların bu kısmında öncelikle bilimsel problem çözme kavramı öğrencilere açıklanmıştır. İlgili örnekler verildikten sonra kendilerini bilimsel problem çözme becerileri noktasında eleştirel bir gözle incelemeleri istenmiştir. Bulgular Matris 2'de sunulmuştur.

Matris 2. Öğrencilerin Bilimsel Problem Çözme Konusundaki Öz Değerlendirmeleri

\begin{tabular}{|c|c|c|c|c|}
\hline & Üst düzey & Orta düzeyde & Düşük düzeyde & Gerekçesi \\
\hline Ö1 & & & $\mathrm{X}$ & $\begin{array}{c}\text { Çözüm önerileri üzerinde düşünürüm ancak her } \\
\text { zaman çözemem. }\end{array}$ \\
\hline Ö2 & & $\mathrm{x}$ & & --- \\
\hline Ö3 & $\mathrm{x}$ & & & --- \\
\hline Ö4 & & $\mathrm{x}$ & & Sıra dışı çözüm yolları bulamam \\
\hline Ö5 & & & $\mathrm{x}$ & Bilimsel soruları araştırma isteğim yok. \\
\hline Ö6 & & $\mathrm{X}$ & & Problem çözmek için çok zaman harcamam. \\
\hline Ö7 & & $\mathrm{X}$ & & $\begin{array}{c}\text { Aklıma çözüm yoları gelir ancak uygulama } \\
\text { kısmında başarılı değilim. }\end{array}$ \\
\hline Ö8 & & $\mathrm{x}$ & & Her zaman çözüm önerileri getiremem. \\
\hline Ö9 & --- & --- & --- & --- \\
\hline Ö10 & & & $\mathrm{x}$ & Bilimsel soruları araştırma isteğim yok. \\
\hline Ö11 & & $\mathrm{x}$ & & Çözüm için çok iyi fikirler üretemem. \\
\hline
\end{tabular}


Matris 2 incelendiğinde bir öğrencinin bu konuda görüş bildirmediği görülmektedir. Görüş bildiren yirmi öğrenciden altısı bilimsel problemleri çözme konusunda kendini yeterli hissederken on bir öğrenci kısmen yeterli görmektedir. Her iki grupta yer alan öğrencilerin görüşleri aşağıda yer almaktadır. Ö${ }_{17}$ bu konudaki tespitlerini “Bilimsel bir problem aklıma gelse şartlarım uygunsa deney yaparım veya kendim bir şeyler yapıp sonucunu bulmaya çalışırım nedenini. O an bulamıyorsam ya da uygun değilsem de onu not alırım daha sonra uygun olduğum zamanda konuyla ilgilenirim.” şeklinde dile getirmiştir. Katılımcılardan $\ddot{O}_{2}$ kodlu öğrenci ise "Bilimsel problemleri çözerken iyiyimdir ama çok iyi değilimdir. “Yaratıcıllk ve problem çözmede kendimi normal görüyorum ama zekâ konusunda kendimi biraz daha üst düzey görebiliyorum.” ifadeleri ile öz değerlendirmede bulunmuştur.

Üç öğrenci ise problem çözme becerisini alt düzeyde bulmaktadır. Ayrıca bazı öğrenciler problem çözmede kendilerini nasıl algıladığına değinmiş ancak açıklayıcı nedenler sunmamıştır. Bu konuda $\mathrm{Ö}_{5}$ kodlu öğrenci "Sürekli bir şeyleri merak ederim ancak araştırma yapmayı pek sevmem.” şeklinde görüşünü ifade etmiştir.

Görüşmelerden elde edilen bulgular genel olarak değerlendirildiğinde öğrencilerin büyük çoğunluğunun zekâ ve yetenek konusunda kendilerinin üstün olduğunu düşündüğü ve yüksek özgüvene sahip olduğu görülmektedir. Ancak aynı öğrenciler bilimsel yaratıcılık ya da problem çözme konusunda aynı şekilde üstün olduğunu düşünmemektedir ve daha düşük bir özgüven sergilemektedir. Öğrencilerin bilimsel yaratıcılık ve problem çözme becerileri konusunda üstün olduğunu düşünenler beş öğrenci iken orta düzeyde olduğunu düşünen öğrenci sayısı on bir kişi civarındadır. Hem bilimsel yaratıcılıkta hem de bilimsel problem 
çözmede kendisini yetersiz hisseden üçer öğrenci bulunmaktadır. Ayrıca her iki konuda görüş bildirmeyen öğrenci sayısı ortalama bir veya iki kişidir.

\section{Tartışma ve Sonuç}

Öz değerlendirme niteliğinde olan bu araştırmada üstün yetenekli öğrencilerin bilimsel yaratıcılık ve problem çözme konularında kendilerine yönelik tespitleri ele alınmıştır. Öğrencileri tanılamaktan ziyade tanımanın amaçlandığı bu araştırmada mülakatlar aracılığı ile çok yönlü bilgiler elde edilmiştir. Renzulli ve Reis (2003) ile birlikte Schroth ve Helfer (2008) üstün yetenekli öğrenciler ile yapılan mülakatların tanıma sürecinde fikir verebildiğini ve öğrencilerin öz değerlendirme yapmalarına firsat tanıdığını dile getirmektedir. Katılımcıların çoğunluğu kendilerini zeki bulmakta ve fende alanında kendilerini üstün yetenekli görmektedir. Bu sonuçlara göre katılımcıların büyük çoğunluğunun zekâ ve yetenek noktasında yüksek bir özgüven sergilediğini söylemek mümkündür. Bilim sanat merkezinde eğitim almanın üst düzey zekâ gerektirdiği düşünen öğrenciler bu noktadan hareketle kendini zeki ve üstün yetenekli görmektedir. Porter (1999) ve Özsoy (2014) da araştırmalarında üstün yeteneklilerin yüksek özgüven içinde olduğunu dile getirmektedir. İnci (2014) ve Özbay (2013) bu özgüvenin bazen aşırı düzeyde olabildiğini ifade etmektedir.

Bilimsel yaratıcılık ve bilimsel problem çözme konularında öğrencilerin öz değerlendirmelerinde şaşırtıcı sonuçlar görülmektedir. Öğrencilerin büyük çoğunluğu zekâ ve yetenek konusunda kendilerinin üstün olduğunu düşünmekte ve özgüvenleri yüksek bir tavır sergilemektedir (Şekil 1). Ancak aynı öğrenciler yaratıcılık ya da problem çözme konusunda aynı şekilde üstün olduğunu düşünmemektedirler ve daha düşük bir özgüven sergilemektedirler. Lin ve arkadaşları (2003) zekânın yaratıcılık için gerekli olduğunu ancak yeterli olmadığını savunmaktadır. Bu yaklaşıma göre zekâ yaratıcılığın ön koşuludur veya bir parçasıdır denebilir. Bu bağlamda her zeki kişinin aynı oranda yaratıcı olmasını beklemek güçtür. Söz konusu öğrenciler ön koşul niteliğindeki zekâya sahip olsalar da yaratıcılık noktasında tüm koşulları yerine getirememiş bireyler olabilir. Yukarıda bahsedilen noktanın araştırmanın çarpıcı bir bulgusu olduğu söylenebilir. Zira üstün yeteneklilerin yaratıcılık ve problem çözme gibi konularda hem kendilerine yönelik algılarında hem de sayısal olarak bu becerilerini göstermede sıkıntı olmayacağı ve muhakkak başarı göstereceği beklentisine girilebilir. Ancak alanyazındaki birçok çalışmada (Batdal Karaduman, 2009; Hacıoğlu ve Türk, 2018; Neihart ve diğ., 2002; Uçar ve diğ., 2017) üstün yeteneklilerin de düşük beceri ya da başarı gösterebileceği noktalar olduğu vurgulanmaktadır. Örneğin Hacığlu ve Türk (2018) 
tarafından üstün yetenekli öğrencilerin yaratıcılık konusunda kendilerine yönelik algılarını incelediği araştırmada üstün yetenekli öğrencilerin kendilerini yaratıcı bulma düzeylerinin ortalamanın altında olduğu sonucuna ulaşılmaktadır. Benzer şekilde Uçar ve arkadaşları (2017) tarafından yapılan çalışmada da üstün yetenekli öğrencilerin problem çözme becerisinin yüksek olmadığı ve sınıf seviyesi ilerledikçe problem çözme becerisinin daha düşük seviyede olduğu belirtilmektedir. Öğrencilerin bazıları genel anlamda kastedilen yaratıc1lıkta kendilerini üst düzeyde (yeterli) görürken bilimsel yaratıcılık konusunda kendilerini aynı şekilde yeterli görememektedir. Bu bağlamda bilimsel yaratıcılık konusunda öğrencilerde genel yaratıcılık konusunda olduğu kadar özgüvenden bahsedilememektedir. Bu noktadaki düşük özgüvenin sebepleri iki noktaya dayandırılabilir. Birincisi; Öğrencilerin zekâ ve yetenek konusundaki farkındalıkları onların yüksek beklentiye girmesine zemin hazırlayabilir. Bir diğer ifade ile üstün yetenekliliğinin farkında olan öğrenciler bilimsel yaratıcılık ve problem çözme konularında da özgüven algısına zarar vererek boyutta yüksek beklentiye girmiş olabilir. Dolayısıyla söz konusu öğrencilerin bilimsel yaratıcılık ve problem çözme konularında üst düzey hedefler koyarak kendilerini yeterli görememiş olabileceği düşünülmektedir. İkincisi; katılımcılardan bazıları özgüven düşüklüğüne sebep olarak içinde bulunulan şartlara atıf yapmaktadır (Şekil 3). Bu noktada eğitim sistemini işaret eden katılımcılar yaratıcılık için uygun ortamların ve zamanın olması gerektiğini savunmaktadır. Beghetto ve Kaufman (2009) da katılımcı ifadelerine benzer ifadeler kullanarak eğitim sürecinde uygun şartlar oluşturulmadığında yaratıcılık potansiyelinin baskılanabildiğini belirtmektedir. Bahsedilen araştırmacılar yaratıcılığın daha çok çocuklarda göründüğünü, yaş ilerledikçe yaratıcılık potansiyelinin azaldığını ve bu sebeple çocukluk yıllarında görülen yaratıcılığın oldukça kıymetli olduğunu ifade etmektedir. Kim (2008) de araştırmasında yukarıda bahsedilen görüşü destekleyerek üstün yeteneklilerin yaklaşık \%30'unun eğitim sistemi ile uyuşamadığını ve yaratıcılıklarının baskılanmasından dolayı liseyi terk ettiğini ifade etmektedir. Reis ve McCoach (2000) ve Ataman (2005) da bu görüşü destekleyerek üstün yetenekli öğrencilerin çoğunun sınırlandırıldığı için okuldan hoşlanmadığını, okulu zaman kaybı olarak gördüğünü belirtmektedir. Dünya tarihinde iz bırakan birçok ünlü bilim insanının okulda sorunlu öğrenciler arasında yer aldığı bilinmektedir. Edison'un okula uyum sağlayamaması sonucu tecrübeli bir öğretmen olan annesi tarafından evinde okutulması bu durum için en iyi bilinen örnek olabilir. $\mathrm{Bu}$ bağlamda yaratıcılık ve problem çözme becerilerinin geliştirilmesi için eğitim ortamlarındaki anlayışın ve imkânların iyileştirilmesi önem arz etmektedir (Bildiren ve Kargın, 2019). 
Bilimsel yaratıcılık ve problem çözme de üstün olduğunu düşünenler beş öğrenci iken orta düzeyde olduğunu düşünen öğrenci sayısı on bir kişi civarındadır. Hem bilimsel yaratıcılıkta hem de bilimsel problem çözmede kendisini yetersiz hisseden üçer öğrenci bulunmaktadır. Ayrıca her iki konuda görüş bildirmeyen öğrenci sayısı ortalama bir veya iki kişidir. Görüş bildirmeyen öğrencilerin görüşmelere kısmen cevap vermesi kendini değerlendirme (self assessment) düzeylerinin düşük olmasından kaynaklanabilir. Zira üstün yetenekli öğrencilerin kendini algılama ile ilgili yapılan çalışmalarda bazı yaş gruplarındaki (ilköğretim düzeyinde) üstün yetenekli öğrencilerin kendini tanıma ve algılama noktasında yetersiz oldukları düşünülmektedir (Shi, Li ve Zhang, 2008; Rudasill ve diğg., 2009; Litster ve Roberts, 2011). Bu noktadan hareketle söz konusu iki öğrenciden neden bilgi alınamadığı gerekçelendirilebilir.

\section{Öneriler}

$\mathrm{Bu}$ araştırmada katılımcıların bilimsel yaratıcılık konusundaki hem öz değerlendirmeleri hem de sıra dışı tespitleri düşündürücü sonuçlar çıkarmaktadır. Öğrencilerin yaratıcılık noktasında özgüvenlerinin yükseltilebilmesi için öğretim sürecinde teşvik edici ortamların oluşturulması önem arz etmektedir. $\mathrm{Bu}$ bağlamda yaratıcılığı geliştirecek etkinliklere vakit ayrılması hususunda bilim sanat merkezindeki ve okullardaki öğretmenlere sorumluluk düştüğü düşünülmektedir. Ayrıca bu araştırmada bilim sanat merkezinde öğrenim gören öğrenciler ile ilgili kavramlardan yola çıkarak mülakat yoluyla nitel sonuçlara ulaşılmıştır. $\mathrm{Bu}$ nedenle araştırmanın anahtar kavramları niteliğinde olan bilimsel yaratıcılık ve problem çözme gibi kavramlar arasındaki ilişkiler ve sonuçlar nicel olarak ortaya konulamamıştır. Bu noktadan hareketle hem nicel hem de nitel sonuçların birlikte ele alındığı ve daha derin bilgiler ortaya koyabilen temsil gücü yüksek karma çalışmalar yapılması araştırmacılara tavsiye edilebilir.

\section{Makalenin Bilimdeki Konumu}

Matematik ve Fen Bilimleri Eğitimi Bölümü/Fen Bilgisi Eğitimi

\section{Makalenin Bilimdeki Özgünlüğü}

Üstün yetenekli öğrencilerin katma değeri yüksek projeler gerçekleştirebilmeleri ve potansiyellerini ortaya koyabilmeleri için öncelikle kendi yeteneklerinin ve kimliklerinin farkına varabilmesi gerektiği düşünülmektedir. Bu amaçla mevcut araştırmada üstün yetenekli öğrencilerin bilimsel yaratıcılık ve bilimsel problem çözme konularında kendilerine öz değerlendirmeleri incelenmiştir. 


\section{Kaynaklar}

Akkanat, Ç. (2019). Bilim ve sanat merkezlerine devam eden ögrencilerin fen yeteneklerini okul iklimi ve akademik katılımın yordaması üzerine bir model çalışması. (Yayımlanmamış doktora tezi). Amasya Üniversitesi, Amasya

Aktamış, H., \& Ergin, Ö. (2006). Fen eğitimi ve yaratıcılık. Dokuz Eylül Üniversitesi Buca Ĕ̈itim Fakültesi Dergisi, 20, 77-83.

Al-Hroub A., \& El-Khoury S. (2018) Definitions and Conceptions of Giftedness Around the World. In: Gifted Education in Lebanese Schools. (pp. 9-37). Springer Briefs in Psychology. Springer, Cham. https://doi.10.1007/978-3-319-78592-9_2

Ataman, A. (2005). Üstün zekâlılar ve üstün yetenekliler. S. Eripek (Ed.), Özel eğitim. Eskişehir: Anadolu Üniversitesi Web Ofset.

Andreasen, N. C. (2009). Yaratıcı beyin dehanın nörobilimi. (Çev: Kıvanç G.). 3. Baskı, Ankara: Arkadaş Yayıncılık.

Batdal Karaduman, G. (2009). Üstün yetenekli öğrencilerde başarı düşüklüğünü önlemek için örnek bir model, International Online Journal of Educational Sciences, 1(1), 196-221.

Beghetto, R. A., \& Kaufman, J. C. (2009). Do we all have multicreative potential?, Mathematics Education, 41,39-44.

Bıçakçı, M., \& Baloğlu, M. (2018). Creativity in research with gifted samples in Turkey, Inonu University Journal of the Faculty of Education, 19(3), 327-343. https://doi:10.17679/inuefd.481895

Bildiren, A., \& Kargın, T. (2019). Proje temelli yaklaşıma dayalı erken müdahale programının üstün yetenekli çocukların problem çözme becerisine etkisi, Eğitim ve Bilim, 44(198), 343-360.

Camcı Erdoğan, S. (2014). Bilimsel yaratıcılı̆̆ temel alan farklılaştırılmış fen ve teknoloji ögrretiminin üstün zekâlı ve yetenekli ögrrencilerin başarı, tutum ve yaratıcılı̆̆ına etkisi. (Yayınlanmamış doktora tezi). İstanbul Üniversitesi, İstanbul

Cevher, A. H., Ertekin, P., \& Köksal, M. S. (2014). Investigation of scientific creativity of eighth grade gifted students, International Journal of Innovation, Creativity and Change, 1(4), 1-8.

Cevher Kılıç, V. (2015). Türkiye'de ütün ve özel yetenekli çocuklara yönelik bir eğitim politikası oluşturulamaması sorunu üzerine bir değerlendirme. 21. Yüzyılda Ĕ̆itim ve Toplum, 4(12), 145-154. 
YYÜ Eğitim Fakültesi Dergisi (YYU Journal of Education Faculty), 2021; 18(1)852-881,http://efdergi.yyu.edu.tr,

Chamberlin, S. A., \& Moon, S. M. (2005). Model-eliciting activities as a tool to develop and identify creatively gifted mathematicians. The Journal of Secondary Gifted Education, 17(1), 37-47.

Çitil, M., \& Ataman, A. (2018). İlköğretim çağındaki üstün yetenekli öğrencilerin davranışsal özelliklerinin eğitim ortamlarına yansıması ve ortaya çıkabilecek sorunlar. Gazi Üniversitesi Ĕ̆itim Fakültesi Dergisi, 38(1), 185-231.

Dawson Saunders, B., \& Trap, R. G. (2004). Basic \& clinical biostatistics. United States: McGraw-Hill Companies, Inc.

DeHaan, R. L. (2009). Teaching creativity and inventive problem solving in science, Life Sciences Education, 8, 172-181. https://doi:10.1187/cbe.08-12- 0081

Demir, D. (2018). Öğrencilerin günlük yaşam ile ilişkilendirme ve algllanan problem çözme becerileri ile rutin ve rutin olmayan problem çözme becerisi arasındaki ilişki. (Yayımlanmamış yüksek lisans tezi). Kocaeli Üniversitesi, Kocaeli.

Feist, G. J. (2006). Domain- spesific creativity in the physical sciences. J. C. Kaufman, \& J. Baer (Eds.), Creativity across domains; faces of the muse (p. 123-138). Mahwah, New Jersey: Lawrence Erlbaum Associates.

Gagne, F. (1985). Giftedness and talent: Reexamining a reexamination of the definitions. Gifted Child Quarterly, 29,103-112.

Hacığlu, Y., \& Türk, T. (2018). Üstün yetenekli öğrenciler kendilerini ne kadar yaratıcı buluyor?. Millli Eğitim Dergisi, 220(Özel Say1), 365-384.

Hadabi, A. S. D. (2010, October). Yemeni Basic Education Teachers’ Perception of Gifted Students' Characteristics and the Methods Used for Identifying These Characteristics. International Conference on Learner Diversity, Bangi, Malaysia. http://www.sciencedirect.com/science. adresinden alınmıştır.

Hong, E., Heo, N., \& Lee, B. (2016). Investigation of 'group scientific creativity' factors in gifted students' creative project solving context. Journal of the Korean Association for Science Education, 36(4), 527-538.

Hou, Y. L. (2009). The relationship between the gifted traits of preschool children and scientific creativity: The mediating effect of the flow experience. Bulletin of Special Education, 34(2), 101-118.

Hu, W., \& Adey P. (2002). A scientific creativity test for secondary school students. International Journal of Science Education, 24(4), 389-403. 
YÜ Eğitim Fakültesi Dergisi (YYU Journal of Education Faculty), 2021; 18(1)852-881, http://efdergi.yyu.edu.tr,

Inci, G. (2014). Üstün yetenekli ögrencilerin sınıf içi davranış sorunlarının belirlenmesi ve çözüm önerileri. (Yayınlanmamış yüksek lisans tezi). Sakarya Üniversitesi, Sakarya.

Kang, J. W., \& Nam, Y. (2017). The impact of engineering design based STEM research experience on gifted students' creative engineering problem solving propensity and attitudes toward engineering. Journal of Korean Association for Science Education, 37(4), 719-730.

Kanlı, E. (2014). Bilimsel yaratıcılığın çağnışımsal temelleri: Model önerisi. Türk Üstün Zekâ ve Ĕ̈itim Dergisi, 4(1), 37-50.

Kanlı, E. (2017). Üstün yetenekli öğrencilerin bilimsel yaratıcılık düzeyleri, cinsiyet ve bilimsel tutumları arasındaki ilişkilerin incelenmesi. Ilköğretim Online, 16(4), 17921802. https://doi: 10.17051/ilkonline.2017.342992

Karaca, T. (2017). Fen öğretiminde yaratıcı zıt düşünme (YAZID) tekniğinin kullanılmasının ortaokul 7. sınıf öğrencilerinin yaratıcılık ve problem çözme becerileri üzerine etkisi. (Yayınlanmamış yüksek lisans tezi). Bülent Ecevit Üniversitesi, Zonguldak.

Karabey, B. (2010). İlköğretimdeki üstün yetenekli öğrencilerin yaratıcı problem çözmeye yönelik erişi düzeylerinin ve kritik düşünme becerilerinin belirlenmesi. (Yayımlanmamış doktora tezi). Dokuz Eylül Üniversitesi, İzmir

Karabey, B., \& Yürümezoğlu, K. (2015). Yaratıcılık ve üstün yetenekliliğin zekâ kuramları açısından değerlendirilmesi. Buca Eğitim Fakültesi Dergisi, 40, 86-105.

Karademir, E. (2016). Investigation the scientific creativity of gifted students through projectbased activities. International Journal of Research in Education and Science, 2(2), 416427.

Kaufman, S. B., \& Sternberg, R. J. (2008). Conceptions of giftedness. In Handbook of giftedness in children (pp. 71-91). Springer, Boston, MA.

Kaufman, J. C., \& Baer, J. (2004). Sure, I'm creative-but not in mathematics. Self-reported creativity in diverse domains, Empirical Studies of the Arts, 22(2), 143-155.

Kim, G. S., \& Choi, S. Y. (2012). The effects of the creative problem solving ability and scientific attitude through the science-based STEAM program in the elementary gifted students, The Korean Elementary Science Education Society, 31, 216-226.

Kim, K. H. (2008). Underachievement and Creativity: Are gifted underachievers highly

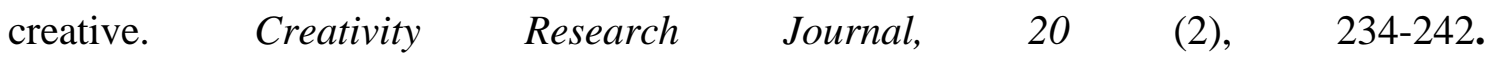
https://doi.org/10.1080/10400410802060232 
YYÜ Eğitim Fakültesi Dergisi (YYU Journal of Education Faculty), 2021; 18(1)852-881,http://efdergi.yyu.edu.tr,

Kim, M., \& Lim, C. (2019). A Comparative analysis of student self-and peer-assessments of elementary science-gifted students' scientific creativity. Journal of Korean Elementary Science Education, 38(4), 439-452

Kim, M. K., Roh, I. S., \& Cho, M. K. (2016). Creativity of gifted students in an integrated math science instruction. Thinking Skills and Creativity, 19, 38-48.

Larroder, A., Ogawa, M. (2015). The development of a self-evaluation checklist for measuring Filipino students' science giftedness. Asia Pacific Science Education, 1-5. https://doi.org/10.1186/s41029-015-0002-0

Liang, J. C. (2002). Exploring scientific creativity of eleventh grade students in taiwan (Phd. Thesis, The University of Texas, Texas, United States). Erişim adresi: http://repositories.lib.utexas.edu/bitstream/handle/2152/1100/liangj026.pdf

Lin, C., Hu W, Adey P., \& Shen J (2003). The Influence of CASE on scientific creativity. Research in Science Education, 33(2), 143-162.

Litster, K., \& Roberts,. J. (2011). The self-concepts and perceived competencies of gifted and non-gifted students: A meta-analysis. Journal of Research in Special Education Needs, 11(2), 130-140.

McGinnis, J. R., \& Kahn, S. (2014). Special needs and talents in science learning. In N. Lederman \& S. Abell (Eds.), Handbook of research on science education (pp. 223-245). New York: Taylor \& Francis.

Miles, M. B., \& Huberman, A. M. (1994). Qualitative data analysis. London: Sage Publications.

Miller, M. (1991). Self-Assessment as a Specific Strategy for Teaching the Gifted Learning Disabled. Journal for the Education of the Gifted, 14(2), 178-188. https://doi.org/10.1177/016235329101400206

Millî Eğitim Bakanlığı, (2013). Üstün yetenekli bireyler strateji ve uygulama planı 20132017. Erişim adresi: http://www.tubitak.gov.tr/sites/default/files/10_ek1_ustunyetenekliler.

Mohamed, A., Maker, C. J., \& Lubart, T. (2012). Exploring the domain specificity of creativity in children: The relationship between a non-verbal creative production test and creative problem-solving activities. Turkish Journal of Giftedness and Education, 2(2), 84-101.

Moravcsik, M. J. (1981). Creativity in science education. Science Education, 65(2), 221-227. 
YYÜ Eğitim Fakültesi Dergisi (YYU Journal of Education Faculty), 2021; 18(1)852-881,http://efdergi.yyu.edu.tr,

Mukhopadhyay, R., \& Sen, M. K. (2013). Scientific creativity- a new emerging field of research: Some considerations, International Journal of Education and Psychological Research, 2(1),1-9.

Neihart, M., Reis, S. M., Robinson, N. M., \& Moon, S. (2002). The social and emotional development of gifted children what do we know? The National Association for Gifted Children: USA.

Nuhoğlu, H., \& Akgül, S. (2019). Analysis of the relation between creativity level and problem solving skills of gifted and talented students. Educational Research and Reviews, 14(15), 518-532.

Orbay, M., Gökdere, M., Tereci, H., \& Aydın, M. (2010). Attitudes of gifted students towards science depending on some variables: A Turkish sample. Scientific Research and Essays, 5(7), 693-699.

Öz Aydın, S., \& Ayverdi, L. (2014). BİLSEM'e kayıtlı olan ve olmayan öğrencilerin çevre sorununa çözüm önerilerinin bilimsel yaratıcılık açısından karşılaştırılması. Türk Fen Ĕ̈itimi Dergisi, 11(1), 25-41.

Özbay, Y. (2013). Üstün yetenekli çocuklar ve aileleri. Ankara: T.C. Aile ve Sosyal Politikalar Bakanlığı Aile ve Toplum Hizmetleri Genel Müdürlüğü Yayını. PDF kitap. ISBN: 978-605-4628-54-4

Özsoy, Y. (2014). Bilim ve sanat merkezi öğrenci, öğretmen ve velilerinin üstün yetenekli öğrenci kavramına ilişkin metaforlar. Üstün Yetenekliler Ĕgitimi Araştırmaları Dergisi, 2(1), 74-87.

Porter, L. (1999). Gifted Young Children, Buckingham, Open University Pres.

Reis, S. M., \& McCoach, D. B. (2000). The underachievement of gifted students: What do we know and where do we go?. Gifted Child Quarterly, 44(3), 152-170.

Renzulli, J. S. (2002). Emerging conceptions of giftedness: Building a bridge to the new century. Exceptionality, 10(2), 67-75.

Renzulli, J. (2005). The Three-Ring Conception of Giftedness: A Developmental Model for Promoting Creative Productivity. In R. Stenberg \& J. Davidson (Eds.), Conceptions of Giftedness (pp. 246-279). Cambridge: Cambridge University Press. doi:10.1017/CBO9780511610455.015

Renzulli, J. S., \& Reis, S. M. (2003). The schoolwide enrichment model: Developing creative and productive giftedness. N. Colangelo, \& G. A. Davis (Eds.), Handbook of gifted education. Boston: Allyn \& Bacon Publishing. 
YYÜ Eğitim Fakültesi Dergisi (YYU Journal of Education Faculty), 2021; 18(1)852-881,http://efdergi.yyu.edu.tr,

Rudasill, K. M., Read Capper, M., Foust, R. C., Callahan, C. M., \& Albaugh, S. B. (2009). Grade and gender differences in gifted students' self-concepts. Journal for the Education of the Gifted, 32(3), 340-367.

Schroth, S. T., Helfer, J. A. (2008). Identifying gifted students: Educators beliefs regarding various policies, processes and procedures. Journal for Education of the Gifted, 32(2), 155-179.

Shaughnessy, M. F., Sak, U. (2013). A reflective conversation with Ugur Sak: Gifted education in Turkey. Gifted Education International, 30(2), 1-9.

Shi, J., Li, Y., \& Zhang, X. (2008). Self-concept of gifted children aged 9 to 13 years old. Journal for the Education of the Gifted, 31(4), 481-500.

Silvia P. J (2015). Intelligence and creativity are pretty similar after all. Educational Psychology Review 27(4), 599-606.

Stenberg, R. J. (2007). Why a cultural approach to giftedness? In S. N. Phillipson \& M. McCann (Eds.), Conceptions of giftedness: Socio-cultural perspectives (pp. 15-18). Mahwah: Lawrence Erlbaum Associates

Szybek, P. (2002). Science Education- An event stagent on two stages simultaneously. Science Educaiton, 11, 525-555.

Şenol, C. (2011). Üstün yetenekliler eğitim programlarına ilişkin öğretmen görüşleri (Bilsem örneği). (Yayımlanmamış yüksek lisans tezi). Fırat Üniversitesi, Elazı̆̆.

Treffinger, D. J., \& Isaksen, S. (2005). Creative problem solving: The history, development, and implications for gifted education and talent development, Gifted Child Quarterly, 49(4), 342-353. DOI:10.1177/001698620504900407

Uçar, F. M., Uçar, M., \& Çalışkan, M. (2017). Investigation of gifted students' problemsolving skills. Journal for the Education of Gifted Young Scientists, 5,1-14.

Usta, E., Akkanat, Ç. (2015). Investigating scientific creativity level of seventh grade students. Procedia Social and Behavioral Sciences, 191,1408-1415.

Ülger, B. B., \& Çepni, S. (2020). Gifted education and STEM: A thematic Review, Journal of Turkish Science Education, 17(3), 443-466.

Wang, Y. C., Kuo, C. C., \& Wu, S. M. (2019). Creative and problem solving thinking of gifted and talented young children observed through classroom dialogues. Universal Journal of Educational Research 7(12), 2677-2692, DOI: 10.13189/ujer.2019.071215

Watters, J. J., \& Diezmann, C. M. (2003). The gifted student in science: Fulfilling potential. Australian Science Teachers Journal, 49(3), 46-53. 
Weisberg, R. W. (2006). Creativity: Understanding innovation in problem solving, science, invention and the arts. Hoboken, New Jersey: John Wiley.

Wirthwein, L., Bergold, S., Preckel, F., \& Steinmayn, R. (2019). Personality and school functioning of intellectually gifted and nongifted adolescents: Self-perceptions and parents' assessments. Learning and Individual Differences, 73, 16-29. https://doi.org/10.1016/j.lindif.2019.04.003

Yıldırım, A., \& Şimşek, H. (2016). Sosyal bilimlerde nitel araştırma yöntemleri. Ankara: Seçkin Yayıncılık. 


\section{Summary}

\section{Problem Statement}

Gifted students are defined as the gems of this world with their potential to produce quality outputs in the future (Orbay et. al., 2010; Şenol, 2011). In Turkey, gifted students are trained in Science and Art Centers to develop their potential in regards to various key concepts such as creativity, problem solving and project work (MoNE, 2013). The literature generally includes studies that mostly address the key concepts of giftedness, scientific creativity and problem solving alone or in combination of another concept (Aktamış and Ergin, 2006; Usta and Akkanat, 2015). In this context, it is believed that there is a need for studies that address the scientific creativity and problem solving skills of gifted students together to allow examining the concept in depth. It is thought that gifted students should be able to realize their own talents and identities in order to be able to realize projects with high added value and reveal their true potential. In other words, self-assessment should be developed in gifted individuals. The present research investigated gifted students' selfassessment on scientific creativity and scientific problem solving.

\section{Method}

This study was designed as a case study with a qualitative research approach. The sample consisted of 21 gifted students at $6^{\text {th }}$ grade studying in Trabzon Science and Art Center. Data were collected from students through semi-structured interviews. A total of four questions were asked to the participants to obtain their views. The data were analyzed by content analysis.

\section{Findings}

Research results demonstrated that most of the participants were interested and curious about science and they regarded themselves to be gifted in science. In addition, it was determined that the students were generally aware of their intelligence and abilities and displayed high self-confidence but did not have the same level of self-confidence in scientific creativity and problem solving.

There were some interesting dialogues were during the interviews. For example, some students emphasized the need for time for creativity, while some students were found to believe that creativity would be lost by $6^{\text {th }}$ grade. It was also stated by the students that the education system would not allow for creativity. The striking results obtained from the interviews were discussed in relation to the education system. 


\section{Discussion and Conclusion}

Striking results were found in students' self-assessment of scientific creativity and problem solving. The vast majority of the participating students believed that they were superior to others in intelligence and talent and they displayed attitudes that pointed to high level of self-confidence. However, the same students did not believe that they were equally superior in creativity or problem solving and they had a lower self-esteem in these regards. Porter (1999) and Özsoy (2014) also reported high self-confidence in gifted people regarding their intelligence.

Some of the participants cited the circumstances they were in as the reason for their low self-confidence in scientific creativity and problem solving. At this point, the participants pointed to the education system and argued that appropriate environments and time should be made available to develop creativity. Using expressions that were similar to these participants' views, Beghetto and Kaufman (2009) also stated that creative potential could be suppressed when appropriate conditions were not created during the education process.

It is important to provide students with encouraging environments in the teaching process to increase their self-confidence in the field of creativity. In this context, it is believed that the teachers employed at the Science and Art Center and at schools have a responsibility to allocate time for activities that will develop creativity. Studies that address themes such as intelligence, creativity and domain-specific creativity that are conducted in association with giftedness can be a field of study for other researchers. 